\title{
Synthesis and reactivity of imido niobium complexes containing the functionalized (dichloromethylsilyl)cyclopentadienyl ligand
}

\author{
Lorena Postigo, Javier Sánchez-Nieves, Pascual Royo * \\ Departamento de Química Inorgánica, Universidad de Alcalá, Campus Universitario, E-28871 Alcalá de Henares, Madrid, Spain
}

Received 20 January 2006; accepted 2 February 2006

Available online 28 February 2006

Dedicated to Prof. Michael Lappert for his outstanding contribution to chemistry.

\begin{abstract}
The niobium complex $\left[\mathrm{NbCp}{ }^{\mathrm{Cl}} \mathrm{Cl}_{4}\right]\left(\mathrm{Cp}^{\mathrm{Cl}}=\eta^{5}-\mathrm{C}_{5} \mathrm{H}_{4}\left(\mathrm{SiCl}_{2} \mathrm{Me}\right)\right.$ ) (1) with a functionalized (dichloromethylsilyl)cyclopentadienyl ligand was isolated by the reaction of $\left[\mathrm{NbCl}_{5}\right]$ with $\mathrm{C}_{5} \mathrm{H}_{4}\left(\mathrm{SiCl}_{2} \mathrm{Me}\right)\left(\mathrm{SiMe}_{3}\right)$. Complex 1 was a precursor for the imido silylamido derivative $\left[\mathrm{NbCp}{ }^{\mathrm{N}} \mathrm{Cl}_{2}(\mathrm{~N} t \mathrm{Bu})\right]\left(\mathrm{Cp}^{\mathrm{N}}=\eta^{5}-\mathrm{C}_{5} \mathrm{H}_{4}[\mathrm{SiClMe}(\mathrm{NH} t \mathrm{Bu})]\right)$ (2) after addition of $\mathrm{LiNH} t \mathrm{Bu}$, which subsequently gave the dichlorosilyl compound $\left[\mathrm{NbCp}^{\mathrm{Cl}} \mathrm{Cl}_{2}(\mathrm{~N} t \mathrm{Bu})\right]$ (3) when reacted with $\mathrm{SiCl}_{3} \mathrm{Me}$. Addition of $\mathrm{LiNH} t \mathrm{Bu}$ to complex 2 gave the niobium amido complex $\left[\mathrm{NbCp}{ }^{\mathrm{N}} \mathrm{Cl}(\mathrm{NH} t \mathrm{Bu})(\mathrm{N} t \mathrm{Bu})\right](4)$, which slowly evolved with exchange of the niobium-amido and the silicon-chloro groups to give the dichloroniobium complex [ $\left.\mathrm{NbCp}^{\mathrm{NN}} \mathrm{Cl}_{2}(\mathrm{~N} t \mathrm{Bu})\right]\left(\mathrm{Cp}^{\mathrm{NN}}=\eta^{5}-\mathrm{C}_{5} \mathrm{H}_{4}\left[\mathrm{SiMe}(\mathrm{NH} t \mathrm{Bu})_{2}\right]\right)(\mathbf{5})$. Reaction of 2 with excess $\mathrm{LiNH} t \mathrm{Bu}$ gave the silyl- $\eta$-amido constrained geometry complexes $\left[\mathrm{Nb}\left\{\eta^{5}-\mathrm{C}_{5} \mathrm{H}_{4}[\mathrm{SiMe}(\mathrm{NH} t \mathrm{Bu})(-\eta-\mathrm{N} t \mathrm{Bu})]\right\}(\mathrm{NH} t \mathrm{Bu})(\mathrm{N} t \mathrm{Bu})\right](\mathbf{6})$ and $\left[\mathrm{Nb}\left\{\eta^{5}-\mathrm{C}_{5} \mathrm{H}_{4}[\mathrm{SiCl}-\right.\right.$ $\mathrm{Me}(-\eta-\mathrm{N} t \mathrm{Bu})]\}(\mathrm{NH} t \mathrm{Bu})(\mathrm{N} t \mathrm{Bu})](7)$, whereas addition of one equimolecular amount of $\mathrm{LiNH} t \mathrm{Bu}$ to 5 in $\mathrm{C}_{6} \mathrm{D}_{6}$ afforded complex $\left[\mathrm{NbCp}{ }^{\mathrm{NN}} \mathrm{Cl}(\mathrm{NH} t \mathrm{Bu})(\mathrm{N} t \mathrm{Bu})\right](\mathbf{8})$. All of the new complexes were characterized by ${ }^{1} \mathrm{H},{ }^{13} \mathrm{C}$ and ${ }^{29} \mathrm{Si} \mathrm{NMR}$ spectroscopy.
\end{abstract}

(C) 2006 Elsevier B.V. All rights reserved.

Keywords: Niobium; Constrained-geometry; Half-sandwich; Imido; Monocyclopentadienyl

\section{Introduction}

The presence of different functionalities attached to the cyclopentadienyl ligands determines both the steric and electronic properties of the metal centres and modifies the reactivity of their complexes [1]. A particularly useful functionality is that containing a chlorosilyl group because the reactivity of the $\mathrm{Si}-\mathrm{Cl}$ bond facilitates the formation of the silyl- $\eta$-amido bridge between the cyclopentadienyl ligand and the metal centre [2-8]. These types of silyl- $\eta$-amido monocyclopentadienyl groups 3 and 4 metal complexes are active catalysts for olefin polymerization (constrainedgeometry catalysts) [9-12] and a rich chemistry has been developed [13-17] since their discovery, showing both sim-

\footnotetext{
* Corresponding author. Tel.: +3491885 4765; fax: +34 918854683. E-mail address: pascual.royo@uah.es (P. Royo).
}

ilarities and differences when compared with related dicyclopentadienyl compounds.

We focused our research interest on studies related to cyclopentadienyl group 4-6 metal complexes supporting modified cyclopentadienyl rings [2-8,18-24], and reported the synthesis of silyl- $\eta$-amido cyclopentadienyl group 4 and 5 metal complexes using the related (chlorodimethylsi1yl)cyclopentadienyl metal derivatives [2-8,24]. Hydrolysis of these compounds also led to the isolation of dinuclear derivatives with $\mathrm{Si}-\mathrm{O}-\mathrm{Si}$ bridges for $\mathrm{Nb}[8,21,25]$, Mo and $\mathrm{W}$ [24] and $\mathrm{Si}-\mathrm{O}-\mathrm{M}$ bridges for $\mathrm{Nb}$ [25] and group 4 metals $[2,26,27]$.

The next step in our research was the introduction of a second $\mathrm{Si}-\mathrm{Cl}$ bond using the (dichloromethylsilyl)cyclopentadienyl ligand or alternatively a second chlorodimethylsilyl group attached to the same cyclopentadienyl ring. These two types of compounds offered the opportunity to introduce a chelating cyclopentadienyl silyl- $\eta$-amido ligand 
whilst still leaving a second reactive point at the cyclopentadienyl ligand. The first type of complex can be illustrated by the reported constrained geometry group 4 metal complexes with one additional $\mathrm{Si}-\mathrm{X}$ bond $(\mathrm{X}=\mathrm{H}, \mathrm{Cl}, \mathrm{NH} t \mathrm{Bu})$ [28-30], which were suitable to explore further reactivity of these bonds. Furthermore, hydrolysis of the $\mathrm{Si}-\mathrm{Cl}$ bond of the starting $\left[\mathrm{Ti}\left\{\eta^{5}-\mathrm{C}_{5} \mathrm{R}_{4}\left(\mathrm{SiCl}_{2} \mathrm{Me}\right)\right\} \mathrm{Cl}_{3}\right](\mathrm{R}=\mathrm{H}, \mathrm{Me})$ complexes gave dinuclear compounds with $\mathrm{Si}-\mathrm{O}-\mathrm{Ti}$ [28] bridges and one additional $\mathrm{Si}-\mathrm{O}-\mathrm{Si}$ bridge (for $\mathrm{R}=\mathrm{Me}$ ) [31]. The second type of compound comprised the bis(silyl- $\eta$ amido)cyclopentadienyl group 4 metal complexes, which were synthesized [14] and studied as a new type of olefin polymerization catalysts. The bis(chlorosilyl)cyclopentadienyl ligand also allowed the synthesis of a dinuclear complex with carbonate ligands bridging the silicon and titanium atoms when hydrolysis of $\left[\mathrm{Ti}\left\{\eta^{5}-\mathrm{C}_{5} \mathrm{H}_{3}-\right.\right.$ $\left.\left.\left(\mathrm{SiClMe}_{2}\right)_{2}\right\} \mathrm{Cl}_{3}\right]$ was carried out in the presence of $\mathrm{CO}_{2}$ [32].

Continuing our studies on the chemistry of metal compounds with modified monocyclopentadienyl ligands, we report here the synthesis of the (dichloromethylsilyl)cyclopentadienyl niobium derivative $\left[\mathrm{Nb}\left\{\eta^{5}-\mathrm{C}_{5} \mathrm{H}_{4}\right.\right.$ $\left.\left.\left(\mathrm{SiCl}_{2} \mathrm{Me}\right)\right\} \mathrm{Cl}_{4}\right]$ and its reactions with lithium amides to give imidodichloro- and imidochloroamido-niobium complexes with aminosilylcyclopentadienyl ligands $[\mathrm{Nb}$ $\left.\left\{\eta^{5}-\mathrm{C}_{5} \mathrm{H}_{4}[\mathrm{SiMeX}(\mathrm{NH} t \mathrm{Bu})]\right\}(\mathrm{N} t \mathrm{Bu}) \mathrm{ClX}\right](\mathrm{X}=\mathrm{Cl}, \mathrm{NH} t \mathrm{Bu})$ and imido(cyclopentadienylsilyl- $\eta$-amido)niobium compounds $\left[\mathrm{Nb}\left\{\eta^{5}-\mathrm{C}_{5} \mathrm{H}_{4}[\mathrm{SiMeX}(-\eta-\mathrm{N} t \mathrm{Bu})]\right\}(\mathrm{NH} t \mathrm{Bu})(\mathrm{N} t \mathrm{Bu})\right]$ $(\mathrm{X}=\mathrm{Cl}, \mathrm{NH} t \mathrm{Bu})$. The comparative reactivity of these compounds is also reported.

\section{Results and discussion}

The use of (trimethylsilyl)silylcyclopentadienyl derivatives $\mathrm{C}_{5} \mathrm{H}_{4}\left(\mathrm{SiMe}_{3}\right) \mathrm{X}$ has been demonstrated to be a successful method to synthesize niobium complexes with functionalized cyclopentadienyl ligands [1]. Following this method, the (dichloromethylsilyl)monocyclopentadienyl niobium compound $\quad\left[\mathrm{NbCp}^{\mathrm{Cl}} \mathrm{Cl}_{4}\right] \quad\left(\mathrm{Cp}^{\mathrm{Cl}}=\eta^{5}-\mathrm{C}_{5} \mathrm{H}_{4}-\right.$ $\left.\left(\mathrm{SiCl}_{2} \mathrm{Me}\right)\right)(\mathbf{1})$ was isolated as a dark red solid by the reaction of $\left[\mathrm{NbCl}_{5}\right]$ with $\mathrm{C}_{5} \mathrm{H}_{4}\left(\mathrm{SiCl}_{2} \mathrm{Me}\right)\left(\mathrm{SiMe}_{3}\right)$ in dichloromethane (Scheme 1). The ${ }^{1} \mathrm{H}$ NMR spectrum of $\mathbf{1}$ showed the typical $\mathrm{AA}^{\prime} \mathrm{BB}^{\prime}$ pattern for the $\mathrm{C}_{5} \mathrm{H}_{4}$ group in complexes with $C_{s}$ symmetry and one resonance at $\delta$ 1.26 for the $\mathrm{SiMeCl}_{2}$ group, shifted to a lower field compared with related compounds supporting $\mathrm{SiClMe}_{2}(\delta$ $0.90)$ [21] and $\mathrm{SiMe}_{3}(\delta 0.41)$ [33] groups, consistent with the increasing number of electron withdrawing groups attached to the silicon atom.

The presence of two types of chlorine atoms, bound to niobium and silicon atoms in compound $\mathbf{1}$, moved us to study their reactivity toward amido and imido transfer reagents. The (silylamido)cyclopentadienyl imido compound $\left[\mathrm{NbCp}^{\mathrm{N}} \mathrm{Cl}_{2}(\mathrm{~N} t \mathrm{Bu})\right] \quad\left(\mathrm{Cp}^{\mathrm{N}}=\eta^{5}-\mathrm{C}_{5} \mathrm{H}_{4}[\mathrm{SiClMe}-\right.$ $(\mathrm{NH} t \mathrm{Bu})])$ (2) was obtained by the reaction of $\mathbf{1}$ with $t \mathrm{BuNH}_{2}, \mathrm{LiNH} t \mathrm{Bu}$ and $t \mathrm{Bu}\left(\mathrm{SiMe}_{3}\right) \mathrm{NH}$ as a yellowish solid. Whatever the conditions, the formation of the puta- tive derivative $\left[\mathrm{NbCp}^{\mathrm{Cl}} \mathrm{Cl}_{2}(\mathrm{~N} t \mathrm{Bu})\right]$ was never observed. This result is clearly influenced by the presence of two chloro ligands at the silicon atom, since the related dimethylmonochlorosilyl derivative $\left[\mathrm{Nb}\left\{\eta^{5}-\mathrm{C}_{5} \mathrm{H}_{4}\left(\mathrm{SiClMe}_{2}\right)\right\} \mathrm{Cl}_{4}\right]$ initially gave the imido complex $\left[\mathrm{Nb}\left\{\eta^{5}-\mathrm{C}_{5} \mathrm{H}_{4}(\mathrm{SiCl}-\right.\right.$ $\left.\left.\left.\mathrm{Me}_{2}\right)\right\} \mathrm{Cl}_{2}(\mathrm{~N} t \mathrm{Bu})\right]$ [21], containing the unaltered silyl substituent. However, 2 could be transformed into $\left[\mathrm{NbCp}^{\mathrm{Cl}} \mathrm{Cl}_{2}(\mathrm{~N} t \mathrm{Bu})\right]$ (3) by the addition of $\mathrm{SiCl}_{3} \mathrm{Me}$, through the chloro-amido exchange reaction. The ${ }^{1} \mathrm{H}$ NMR spectrum of compound 2 showed the ABCD pattern for the $\mathrm{C}_{5} \mathrm{H}_{4}$ group expected for the presence of a chiral silicon atom, whereas for compound 3 the $\mathrm{AA}^{\prime} \mathrm{BB}^{\prime}$ pattern observed for 1 was recovered. The ${ }^{1} \mathrm{H}$ and ${ }^{13} \mathrm{C}$ NMR spectra of 2 showed signals corresponding to the presence of two different $t \mathrm{Bu}$ groups, whereas the ${ }^{1} \mathrm{H}$ and ${ }^{13} \mathrm{C}$ NMR spectra of $\mathbf{3}$ only showed signals for one $t \mathrm{Bu}$ group. The ${ }^{29} \mathrm{Si}$ NMR spectra were the most useful spectroscopic means to distinguish a silicon-amido bond from a niobium-amido bond in complex $\mathbf{2}$, the resonance observed at $\delta-9.8$ was clearly shifted highfield compared to the values found for compounds 1 and $3, \delta 12.0$ and $\delta$ 13.4, respectively, supporting the presence of two chloro ligands at the silicon atom.

Compound 2 reacted with one additional equivalent of $\mathrm{LiNH} t \mathrm{Bu}$ to give the chloro amido niobium complex $\left[\mathrm{NbCp}{ }^{\mathrm{N}} \mathrm{Cl}(\mathrm{NH} t \mathrm{Bu})(\mathrm{N} t \mathrm{Bu})\right](4)$ isolated as a mixture of diastereoisomers, due to the presence of two stereogenic centres, at silicon and niobium atoms, demonstrating the substitution of one chloro ligand at the metal centre. The diastereoisomers were in a 1:0.5 molar ratio and were identified by the two ABCD sets of signals observed in the ${ }^{1} \mathrm{H}$ NMR spectrum for each $\mathrm{C}_{5} \mathrm{H}_{4}$ group and one resonance for each isomer in the ${ }^{29} \mathrm{Si}$ NMR spectrum at around $\delta-8$, very close to that observed for the starting complex 2 . The presence of a niobium-amido group was also confirmed by the lowfield shifted resonance above $\delta 8$ for the $\mathrm{Nb}-\mathrm{NH} t$ Bu proton compared with the signal shifted highfield $(\delta 1-3)$ observed for the related aminosilyl $\mathrm{Si}-\mathrm{NH} t \mathrm{Bu}$ group.

Complex 4 is the kinetic product of the reaction, since heating a $\mathrm{C}_{6} \mathrm{D}_{6}$ solution of 4 or leaving the oily mixture of diastereoisomers of $\mathbf{4}$ at room temperature for several days gave the bisamidosilyl complex $\left[\mathrm{Nb}\left\{\eta^{5}-\mathrm{C}_{5} \mathrm{H}_{4}[\mathrm{Si}-\right.\right.$ $\left.\left.\left.\mathrm{Me}(\mathrm{NH} t \mathrm{Bu})_{2}\right]\right\} \mathrm{Cl}_{2}(\mathrm{~N} t \mathrm{Bu})\right](\mathbf{5})$, isolated as a brownish oil. A similar behaviour was observed in the reaction of the related imido niobium complex $\left[\mathrm{Nb}\left\{\eta^{5}-\mathrm{C}_{5} \mathrm{H}_{4}\right.\right.$ $\left.\left.\left(\mathrm{SiClMe}_{2}\right)\right\} \mathrm{Cl}_{2}(\mathrm{~N} t \mathrm{Bu})\right]$ with $\mathrm{LiNH} t \mathrm{Bu}$ [7], which proved to be an intermolecular process. In this case, the ${ }^{1} \mathrm{H}$ NMR spectrum of $\mathbf{5}$ again showed an $\mathrm{AA}^{\prime} \mathrm{BB}^{\prime}$ pattern, after recovering the $C_{s}$ symmetry; meanwhile, the ${ }^{29} \mathrm{Si}$ NMR spectrum showed a resonance shifted highfield $(\delta$ -29.0 ), due to the presence of two $\pi$ donor amido ligands bound to the silicon atom $[29,30]$. Furthermore, the resonances at low field of the $\mathrm{H}-\mathrm{N}$ niobium-amido groups disappeared, although the new resonances for the siliconamido ligands could not be observed.

Following the same method based on using the imido chlorosilyl- and (amidosilyl)-monocyclopentadienyl 


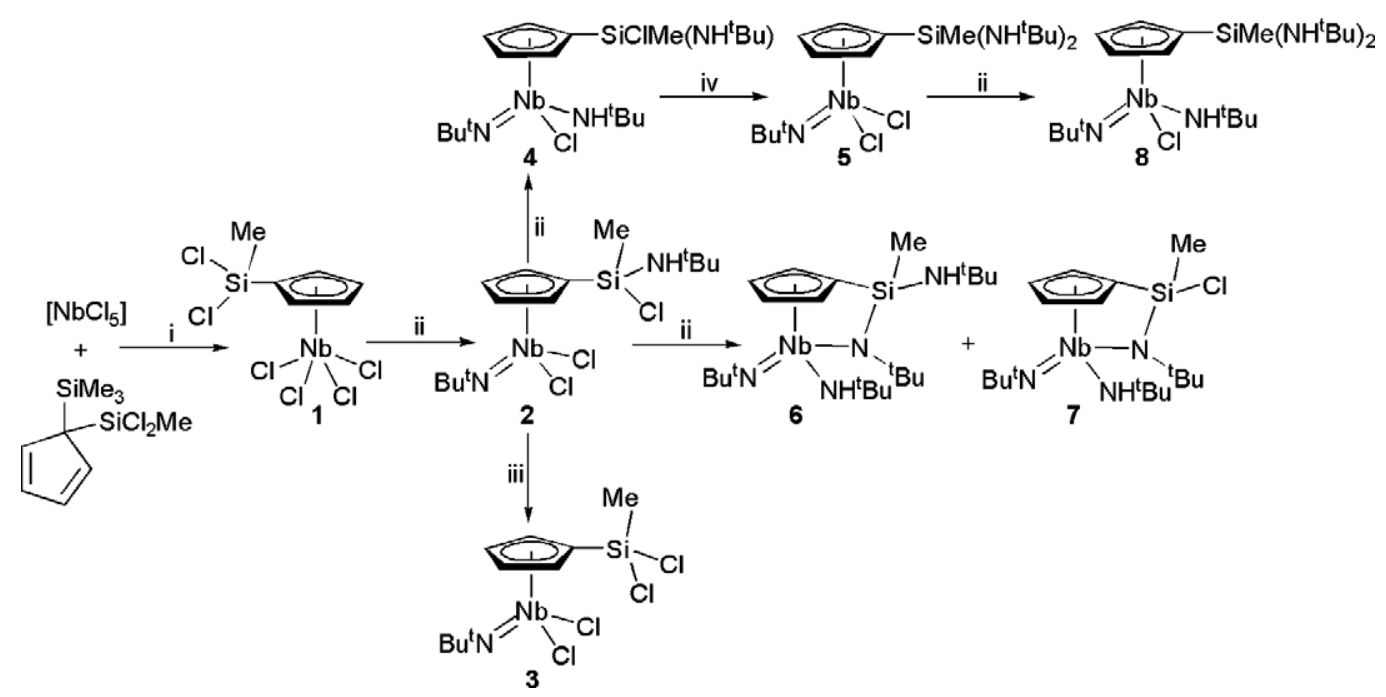

Scheme 1. (i) $\mathrm{CH}_{2} \mathrm{Cl}_{2}, 20^{\circ} \mathrm{C}$; (ii) $t \mathrm{BuNHLi}$; (iii) $\mathrm{SiCl}_{3} \mathrm{Me}$; (iv) $20^{\circ} \mathrm{C}, 4 \mathrm{~d}$.

niobium compounds as precursors to isolate silyl- $\eta$-amido complexes [7,8,34], compound $\mathbf{2}$ was treated with excess $\mathrm{LiNH} t \mathrm{Bu}$ to give a brownish oily residue after removal of the solvent. Substitution of all of the $\mathrm{Si}-\mathrm{Cl}$ by $\mathrm{Si}-\mathrm{NH} t \mathrm{Bu}$ bonds with simultaneous generation of the cyclopentadienylsilyl-n-amido system would result in formation of the constrained geometry complex $\left[\mathrm{Nb}\left\{\eta^{5}-\mathrm{C}_{5} \mathrm{H}_{4}[\mathrm{SiMe}-\right.\right.$ $(\mathrm{NH} t \mathrm{Bu})(-\eta-\mathrm{N} t \mathrm{Bu})]\}(\mathrm{NH} t \mathrm{Bu})(\mathrm{N} t \mathrm{Bu})] \quad$ (6). Complex 6 should show two stereogenic centres at the silicon and niobium atoms and it should therefore give a mixture of two enantiomeric pairs of diastereoisomers. The ${ }^{1} \mathrm{H}$ NMR spectrum of the oily residue confirmed the presence of two components, although only one of them showed the four $t \mathrm{Bu}$ singlets expected for one diastereoisomer of $\mathbf{6}$, while four similar singlets assigned to the other diastereoisomer were not observed. The structure proposed for compound $\mathbf{6}$ is consistent with the highfield shifted signal observed in the ${ }^{13} \mathrm{C}$ NMR spectrum at $\delta 104.7$, corresponding to the $\mathrm{C}_{i p s o}$ of the $\mathrm{C}_{5} \mathrm{H}_{4}$ ligand, and the ${ }^{29} \mathrm{Si}$ NMR resonance shifted highfield $(\delta-41.0)$ as expected for its bridging coordination, compared with the parent unbridged complex $5(\delta-29.0)$.

The second component of the oily mixture (molar ratio 6:7 $=1: 3$ ) of reaction products could not be identified as a diastereoisomer of $\mathbf{6}$, because the ${ }^{1} \mathrm{H}$ NMR spectrum showed only three $t \mathrm{Bu}$ resonances. Instead, we believe that this component is the chloro-silyl constrained geometry derivative $\left[\mathrm{Nb}\left\{\eta^{5}-\mathrm{C}_{5} \mathrm{H}_{4}[\mathrm{SiClMe}(-\eta-\mathrm{N} t \mathrm{Bu})]\right\}(\mathrm{NH} t \mathrm{Bu})(\mathrm{N} t \mathrm{Bu})\right]$ (7), with one $\mathrm{Si}-\mathrm{Cl}$ bond still remaining. This formulation is consistent with the ${ }^{29} \mathrm{Si}$ NMR spectrum which showed a signal at $\delta-30$, clearly shifted highfield with respect to the unbridged parent complex 2 , but shifted lowfield with respect to the related aminosilyl- $\eta$-amido complex $\mathbf{6}$, with the silicon atom supporting two amido substituents. Unfortunately, the ${ }^{13} \mathrm{C}$ NMR resonance corresponding to the $\mathrm{C}_{i p s o}$ of the $\mathrm{C}_{5} \mathrm{H}_{4}$ ligand could not be located. However, addition of excess amount of $\mathrm{LiNH} t \mathrm{Bu}$ to $\mathbf{2}$ or to the mixture of $\mathbf{6}$ and $\mathbf{7}$ did not modify the results described above.
In an additional attempt to isolate a new silyl- $\eta$-amido constrained geometry complex, we added an equimolecular amount of $\mathrm{LiNH} t \mathrm{Bu}$ to a $\mathrm{C}_{6} \mathrm{D}_{6}$ solution of $\mathbf{5}$. This reaction afforded the new niobium amido derivative $\left[\mathrm{Nb}\left\{\eta^{5}-\mathrm{C}_{5} \mathrm{H}_{4}\right.\right.$ $\left.\left.\left[\mathrm{SiMe}(\mathrm{NH} t \mathrm{Bu})_{2}\right]\right\} \mathrm{Cl}(\mathrm{NH} t \mathrm{Bu})(\mathrm{N} t \mathrm{Bu})\right](\mathbf{8})$ as the unique reaction product. Compound $\mathbf{8}$ could not be isolated, and was only detected by its spectroscopic data, which were clearly different from those observed for 7 . The ${ }^{1} \mathrm{H}$ NMR spectrum of $\mathbf{8}$ showed four $t \mathrm{Bu}$ singlets, one resonance at $\delta 8.20$ for the $\mathrm{H}-\mathrm{N}$ proton of the $\mathrm{Nb}-\mathrm{NH} t \mathrm{Bu}$ group and one resonance at $\delta-27.7$ in the ${ }^{29} \mathrm{Si} \mathrm{NMR}$ spectrum, very similar to that found for the starting compound $\mathbf{5}$.

\section{Conclusions}

The niobium complex $\left[\mathrm{NbCp}^{\mathrm{Cl}} \mathrm{Cl}_{4}\right] \quad\left(\mathrm{Cp}^{\mathrm{Cl}}=\eta^{5}\right.$ $\mathrm{C}_{5} \mathrm{H}_{4}\left(\mathrm{SiCl}_{2} \mathrm{Me}\right)$ ) with the functionalized (dichloromethylsilyl)cyclopentadienyl ligand was isolated in high yield by the reaction of $\left[\mathrm{NbCl}_{5}\right]$ with the silylated ring-transfer reagent $\mathrm{C}_{5} \mathrm{H}_{4}\left(\mathrm{SiCl}_{2} \mathrm{Me}\right)\left(\mathrm{SiMe}_{3}\right)$. The presence of two $\mathrm{Si}-\mathrm{Cl}$ bonds in the molecule prevented the transformation of $\mathbf{1}$ into the imido derivative $\left[\mathrm{NbCp}^{\mathrm{Cl}} \mathrm{Cl}_{2}(\mathrm{~N} t \mathrm{Bu})\right]$ when reactions with $t \mathrm{BuNH}_{2}, \mathrm{LiNH} t \mathrm{Bu}$ or $t \mathrm{Bu}\left(\mathrm{SiMe}_{3}\right) \mathrm{NH}$ were carried out, rather the monoamidosilyl imido complex [Nb$\left.\mathrm{Cp}^{\mathrm{N}} \mathrm{Cl}_{2}(\mathrm{~N} t \mathrm{Bu})\right] \quad\left(\mathrm{Cp}^{\mathrm{N}}=\eta^{5}-\mathrm{C}_{5} \mathrm{H}_{4}[\mathrm{SiClMe}(\mathrm{NH} t \mathrm{Bu})]\right) \quad$ was obtained. However, a further amido-chloro exchange reaction with $\mathrm{SiCl}_{3} \mathrm{Me}$ afforded $\left[\mathrm{NbCp}^{\mathrm{Cl}} \mathrm{Cl}_{2}(\mathrm{~N} t \mathrm{Bu})\right]$. The $\mathrm{Nb}-$ $\mathrm{Cl}$ bond in compound $\left[\mathrm{NbCp}^{\mathrm{N}} \mathrm{Cl}_{2}(\mathrm{~N} t \mathrm{Bu})\right]$ is kinetically more reactive than the remaining $\mathrm{Si}-\mathrm{Cl}$ bond in its reaction with $\mathrm{LiNH} t \mathrm{Bu}$, giving $\left[\mathrm{NbCp}{ }^{\mathrm{N}} \mathrm{Cl}(\mathrm{NH} t \mathrm{Bu})(\mathrm{N} t \mathrm{Bu})\right]$, which after several days was transformed into the thermodynamic product $\left[\mathrm{NbCp}^{\mathrm{NN}} \mathrm{Cl}_{2}(\mathrm{~N} t \mathrm{Bu})\right]\left(\mathrm{Cp}^{\mathrm{NN}}=\eta^{5}-\mathrm{C}_{5} \mathrm{H}_{4}[\mathrm{SiClMe}-\right.$ $(\mathrm{NH} t \mathrm{Bu})])$. All of these imido complexes were suitable precursors for constrained geometry complexes, although their reactions with excess $\mathrm{LiNH} t \mathrm{Bu}$ always gave unresolvable mixtures of $\left[\mathrm{Nb}\left\{\eta^{5}-\mathrm{C}_{5} \mathrm{H}_{4}[\mathrm{SiMe}(\mathrm{NH} t \mathrm{Bu})(-\eta-\mathrm{N} t \mathrm{Bu})]\right\}-\right.$ $(\mathrm{NH} t \mathrm{Bu})(\mathrm{N} t \mathrm{Bu})]$ and $\left[\mathrm{Nb}\left\{\eta^{5}-\mathrm{C}_{5} \mathrm{H}_{4}[\mathrm{SiClMe}(-\eta-\mathrm{N} t \mathrm{Bu})]\right\}-\right.$ $(\mathrm{NH} t \mathrm{Bu})(\mathrm{N} t \mathrm{Bu})]$. 


\section{Experimental}

All manipulations were performed under argon atmosphere, using standard Schlenk techniques or a glovebox. The solvents used were previously dried and freshly distilled under argon: diethylether and tetrahydrofuran from sodium benzophenone ketyl and hexane from sodiumpotassium amalgam. Deuterated solvents from Scharlau were degassed and stored over molecular sieves. NMR spectra were recorded on a Varian Unity FT-300 and chemical shifts are given in $\mathrm{ppm}(\delta)$. The ${ }^{29} \mathrm{Si}$ NMR spectra were registered by gHMBC ${ }^{29} \mathrm{Si}^{-1} \mathrm{H}$ experiments. $\mathrm{C}, \mathrm{H}$ and $\mathrm{N}$ microanalyses were performed on a Perkin-Elmer 240B microanalyzer. Unless otherwise stated, reagents were obtained from commercial sources and used as received. $t \mathrm{BuNH}_{2}$ (Aldrich) were distilled before use and stored under argon. $\mathrm{LiNH} t \mathrm{Bu}$ was prepared in hexane in quantitative yield from $t \mathrm{BuNH}_{2}$ and $n \mathrm{BuLi}$ (Aldrich, $1.6 \mathrm{M}$ in hexane). $\mathrm{C}_{5} \mathrm{H}_{4}\left(\mathrm{SiCl}_{2} \mathrm{Me}\right)\left(\mathrm{SiMe}_{3}\right)$ [28] was prepared according to the literature procedures.

\section{1. $\left[\mathrm{Nb}\left\{\eta^{5}-\mathrm{C}_{5} \mathrm{H}_{4}\left(\mathrm{SiCl}_{2} \mathrm{Me}\right)\right\} \mathrm{Cl}_{4}\right]$ (1)}

A suspension of $\left[\mathrm{NbCl}_{5}\right](3.24 \mathrm{~g}, 11.99 \mathrm{mmol})$ in dichloromethane $(50 \mathrm{~mL})$ was treated dropwise with a solution of $\mathrm{C}_{5} \mathrm{H}_{4}\left(\mathrm{SiMe}_{3}\right)\left(\mathrm{SiCl}_{2} \mathrm{Me}\right)(3.01 \mathrm{~g}, 11.99 \mathrm{mmol})$ in dichloromethane $(25 \mathrm{~mL})$ and the mixture was stirred for $16 \mathrm{~h}$ at room temperature. The solvent was removed under vacuum to ca. $30 \mathrm{~mL}$. After addition of hexane $(20 \mathrm{~mL})$, the remaining solution was cooled to $-30{ }^{\circ} \mathrm{C}$ to give complex 1 as a red solid $(4.75 \mathrm{~g}, 96 \%$ yield). NMR data for $1\left(\mathrm{CDCl}_{3}\right):{ }^{1} \mathrm{H}: 1.26(\mathrm{~s}, 3 \mathrm{H}, M e), 7.37$ $\left(\mathrm{m}, 2 \mathrm{H}, \mathrm{C}_{5} H_{4}\right), 7.51\left(\mathrm{~m}, 2 \mathrm{H}, \mathrm{C}_{5} \mathrm{H}_{4}\right) ;{ }^{13} \mathrm{C}: 5.2(\mathrm{Si} \mathrm{Me})$, $127.7\left(C_{5} \mathrm{H}_{4}\right), 128.3 \quad\left(C_{5} \mathrm{H}_{4}\right), 129.9\left(C_{i}, C_{5} \mathrm{H}_{4}\right) ;{ }^{29} \mathrm{Si}:$ 12.0. Anal. Calc. for $\mathrm{C}_{6} \mathrm{H}_{7} \mathrm{Cl}_{6} \mathrm{NbSi}$ : C, 17.44; $\mathrm{H}, 1.69$. Found: C, 17.62; H, 1.8\%.

\section{2. $\left[\mathrm{Nb}\left\{\eta^{5}-\mathrm{C}_{5} \mathrm{H}_{4}[\mathrm{SiClMe}(\mathrm{NHtBu})]\right\} \mathrm{Cl}_{2}(\mathrm{NtBu})\right]$ (2)}

A solution of lithium amide $\mathrm{LiNH} t \mathrm{Bu} \quad(1.21 \mathrm{~g}$, $15.38 \mathrm{mmol})$ in toluene $(40 \mathrm{~mL})$ was added dropwise to a previously cooled $\left(-78^{\circ} \mathrm{C}\right)$ solution of $1 \quad(3.17 \mathrm{~g}$, $7.69 \mathrm{mmol})$ and $\mathrm{NEt}_{3}(1.07 \mathrm{~mL}, 7.69 \mathrm{mmol})$ in toluene $(50 \mathrm{~mL})$. The reaction mixture was warmed to room temperature and stirred overnight. Afterwards, the volatiles were removed under vacuum to yield a yellow residue, which was extracted into hexane. Removal of the solvent yielded a yellow solid identified as $2(3.00 \mathrm{~g}, 87 \%$ yield $)$. NMR data for $2\left(\mathrm{C}_{6} \mathrm{D}_{6}\right):{ }^{1} \mathrm{H}: 0.71(\mathrm{~s}, 3 \mathrm{H}, M e), 1.07(\mathrm{~s}$, $9 \mathrm{H}, t B u), 1.14(\mathrm{~s}, 9 \mathrm{H}, t B u), 2.00$ (bs, $1 \mathrm{H}, \mathrm{SiNH} t \mathrm{Bu}), 5.95$ $\left(\mathrm{m}, 1 \mathrm{H}, \mathrm{C}_{5} H_{4}\right), 6.01\left(\mathrm{~m}, 1 \mathrm{H}, \mathrm{C}_{5} H_{4}\right), 6.54\left(\mathrm{~m}, 1 \mathrm{H}, \mathrm{C}_{5} H_{4}\right)$, $6.64\left(\mathrm{~m}, 1 \mathrm{H}, \mathrm{C}_{5} H_{4}\right) ;{ }^{13} \mathrm{C}: 5.6(\mathrm{Si} M e), 30.4(\mathrm{Me}, t \mathrm{Bu}), 33.2$ $(M e, t \mathrm{Bu}), 58.8\left(C_{i}, \mathrm{SiNH} t B u\right), 70.5\left(C_{i}, \mathrm{Nb}(\mathrm{N} t B u)\right)$, $110.8\left(C_{5} \mathrm{H}_{4}\right), 111.2\left(C_{5} \mathrm{H}_{4}\right), 120.6\left(C_{i}, C_{5} \mathrm{H}_{4}\right), 123.6$ $\left(C_{5} \mathrm{H}_{4}\right), 123.7 \quad\left(C_{5} \mathrm{H}_{4}\right) ;{ }^{29} \mathrm{Si}:-9.8$. Anal. Calc. for $\mathrm{C}_{14} \mathrm{H}_{26} \mathrm{Cl}_{3} \mathrm{~N}_{2} \mathrm{NbSi}$ : C, 37.39; H, 5.78; N, 6.23. Found: C, $39.54 ; \mathrm{H}, 6.47$; N, 5.87\%.

\section{3. $\left[\mathrm{Nb}\left\{\eta^{5}-\mathrm{C}_{5} \mathrm{H}_{4}\left(\mathrm{SiCl}_{2} \mathrm{Me}\right)\right\} \mathrm{Cl}_{2}(\mathrm{NtBu})\right](3)$}

Methyltrichlorosilane $(1.13 \mathrm{~mL}, 9.70 \mathrm{mmol})$ was added at once to a solution of $2(2.18 \mathrm{~g}, 4.85 \mathrm{mmol})$ in $50 \mathrm{~mL}$ of toluene at room temperature. The mixture was stirred for $48 \mathrm{~h}$ and the volatiles were removed to yield $\mathbf{3}$ as a yellow solid $(1.80 \mathrm{~g}, 90 \%$ yield $)$. NMR data for $3\left(\mathrm{C}_{6} \mathrm{D}_{6}\right)$ : ${ }^{1} \mathrm{H}$ : $0.85(\mathrm{~s}, 3 \mathrm{H}, M e), 1.01(\mathrm{~s}, 9 \mathrm{H}, t B u), 5.90\left(\mathrm{~m}, 2 \mathrm{H}, \mathrm{C}_{5} H_{4}\right)$, $6.41\left(\mathrm{~m}, 2 \mathrm{H}, \mathrm{C}_{5} H_{4}\right) ;{ }^{13} \mathrm{C}: 6.1(\mathrm{Si} M e), 30.1(\mathrm{Me}, t \mathrm{Bu})$, $70.7\left(C_{i}, \mathrm{Nb}-\mathrm{N} t \mathrm{Bu}\right), 111.3\left(C_{5} \mathrm{H}_{4}\right), 117.4\left(C_{i}, C_{5} \mathrm{H}_{4}\right), 122.5$ $\left(C_{5} \mathrm{H}_{4}\right) ;{ }^{29} \mathrm{Si}$ : 13.43. Anal. Calc. for $\mathrm{C}_{10} \mathrm{H}_{16} \mathrm{Cl}_{4} \mathrm{NNbSi}$ : C, 29.08; H, 3.87; N, 3.39. Found: C, 30.26; H, 4.08; N, 3.36\%.

\section{4. $\left[\mathrm{Nb}\left\{\eta^{5}-\mathrm{C}_{5} \mathrm{H}_{4}[\mathrm{SiClMe}(\mathrm{NHtBu})]\right\}-\right.$ $\mathrm{Cl}(\mathrm{NHtBu})(\mathrm{NtBu})](\mathbf{4})$}

A solution of $2(0.50 \mathrm{~g}, 1.11 \mathrm{mmol})$ in hexane $(20 \mathrm{~mL})$ was treated dropwise with a solution of $\mathrm{LiNH} t \mathrm{Bu}(0.08 \mathrm{~g}$, $1.11 \mathrm{mmol}$ ) in $20 \mathrm{~mL}$ of hexane and this mixture was stirred for $16 \mathrm{~h}$ at room temperature. The solution was filtered and the solvent was removed to yield an oily mixture of diastereoisomers $\mathbf{4 a}$ and $\mathbf{4 b}$ in a 1:0.5 molar ratio $(0.43 \mathrm{~g}, 80 \%$ yield). NMR data for $\mathbf{4 a} / \mathbf{4 b}\left(\mathrm{C}_{6} \mathrm{D}_{6}\right):{ }^{1} \mathrm{H}: 0.65$ (s, $\left.3 \mathrm{H}, \mathrm{Me}\right)$ (4a), 0.79 (s, 3H, Me) (4b), $1.09(\mathrm{~s}, 9 \mathrm{H}, t B u)(\mathbf{4 b}), 1.17$ (s, $9 \mathrm{H}, t B u)(\mathbf{4 a}), 1.20(\mathrm{~s}, 9 \mathrm{H}, t B u)(\mathbf{4 b}), 1.26(\mathrm{~s}, 9 \mathrm{H}, t B u)$ (4a), $1.34(\mathrm{~s}, 9 \mathrm{H}, t B u)(\mathbf{4 b}), 1.36(\mathrm{~s}, 9 \mathrm{H}, t B u)(\mathbf{4 a}), 1.69$ (bs, $1 \mathrm{H}, \mathrm{SiNH} H \mathrm{Bu})(\mathbf{4 b}), 3.15$ (bs, $1 \mathrm{H}, \mathrm{SiNH} H \mathrm{Bu})(\mathbf{4 a})$, $5.91\left(\mathrm{~m}, 1 \mathrm{H}, \mathrm{C}_{5} H_{4}\right)(\mathbf{4 a}), 5.97\left(\mathrm{~m}, 1 \mathrm{H}, \mathrm{C}_{5} H_{4}\right)(\mathbf{4 b}), 6.11$ $\left(\mathrm{m}, 1 \mathrm{H}, \mathrm{C}_{5} H_{4}\right)(\mathbf{4 a}), 6.12\left(\mathrm{~m}, 1 \mathrm{H}, \mathrm{C}_{5} H_{4}\right)(\mathbf{4 b}), 6.39(\mathrm{~m}$, $\left.1 \mathrm{H}, \mathrm{C}_{5} H_{4}\right)(\mathbf{4 b}), 6.45\left(\mathrm{~m}, 1 \mathrm{H}, \mathrm{C}_{5} H_{4}\right)(\mathbf{4 a}), 6.58(\mathrm{~m}, 1 \mathrm{H}$, $\left.\mathrm{C}_{5} H_{4}\right)(\mathbf{4 a}), 6.61\left(\mathrm{~m}, 1 \mathrm{H}, \mathrm{C}_{5} H_{4}\right)(\mathbf{4 b}), 8.54(\mathrm{bs}, 1 \mathrm{H}, \mathrm{NbN}$ $H t \mathrm{Bu})(\mathbf{4 b}), 8.98(\mathrm{bs}, 1 \mathrm{H}, \mathrm{NbNH} H \mathrm{Bu})(\mathbf{4 a}) ;{ }^{13} \mathrm{C}: 5.5(\mathrm{Si}$ Me) (4b), 7.2 (SiMe (4a), 30.2, 31.8, 31.8, 33.1, 33.3, 33.5 $(\mathrm{Me}, t \mathrm{Bu})(\mathbf{4 a}, \mathbf{4 b}), 50.6,50.7,58.0,58.2,70.6,70.7\left(C_{i}\right.$, $t \mathrm{Bu})(\mathbf{4 a}, \mathbf{4 b}), 106.2,109.1,110.6,111.0,117.8,118.8$, $123.8,124.6\left(C_{5} \mathrm{H}_{4}\right)(\mathbf{4 a}, 4 \mathbf{b}),\left(C_{i}, C_{5} \mathrm{H}_{4}\right.$ not observed); ${ }^{29} \mathrm{Si}:-7.8 \mathrm{ppm}(\mathbf{4 a}),-8.5 \mathrm{ppm}(\mathbf{4 b})$.

\section{5. $\left[\mathrm{Nb}\left\{\eta^{5}-\mathrm{C}_{5} \mathrm{H}_{4}\left[\mathrm{SiMe}(\mathrm{NHtBu})_{2}\right]\right\} \mathrm{Cl}_{2}(\mathrm{NtBu})\right]$ (5)}

An oily mixture of $4(0.50 \mathrm{~g}, 1.02 \mathrm{mmol})$ was left at room temperature for 5 days, isolating $\mathbf{5}$ as a brownish oil $(0.50 \mathrm{~g}, 100 \%$ yield $)$. NMR data for $5\left(\mathrm{C}_{6} \mathrm{D}_{6}\right)$ : ${ }^{1} \mathrm{H}$ : $0.54(\mathrm{~s}, 3 \mathrm{H}, M e), 1.08(\mathrm{~s}, 9 \mathrm{H}, t B u), 1.22(\mathrm{~s}, 18 \mathrm{H}, t B u)$, $6.09\left(\mathrm{~m}, 2 \mathrm{H}, C_{5} H_{4}\right), 6.35\left(\mathrm{~m}, 2 \mathrm{H}, C_{5} H_{4}\right)$, (SiNHtBu not observed); ${ }^{13} \mathrm{C}: 3.3$ (SiMe) $30.3(M e, t \mathrm{Bu}), 33.6(M e$, $t \mathrm{Bu}), 50.6\left(C_{i}, \mathrm{SiNH} t B u\right), 69.8\left(\mathrm{C}_{i}, \mathrm{Nb}(\mathrm{N} t B u)\right), 108.9$ $\left(C_{5} \mathrm{H}_{4}\right), 123.6\left(C_{5} \mathrm{H}_{4}\right),\left(C_{i}, C_{5} \mathrm{H}_{4}\right.$ not observed $) ;{ }^{29} \mathrm{Si}$ : -29.0. Anal. Calc. for $\mathrm{C}_{18} \mathrm{H}_{36} \mathrm{Cl}_{2} \mathrm{~N}_{3} \mathrm{NbSi}$ : C, 44.46; $\mathrm{H}$, 7.41; N, 8.64. Found: C, 44.06; H, 6.93; N, 8.03\%.

\section{6. $\left[\mathrm{Nb}\left\{\eta^{5}-\mathrm{C}_{5} \mathrm{H}_{4}[\mathrm{SiMe}(\mathrm{NHtBu})(-\eta-\mathrm{NtBu})]\right\}(\mathrm{NHtBu})-\right.$} $(\mathrm{NtBu})](\mathbf{6})$ and $\left[\mathrm{Nb}\left\{\eta^{5}-\mathrm{C}_{5} \mathrm{H}_{4}[\mathrm{SiClMe}(-\eta-N t \mathrm{Bu})]\right\}\right.$ $(\mathrm{NHtBu})(\mathrm{NtBu})](7)$

A solution of 5 equiv. of $\mathrm{LiNH} t \mathrm{Bu}(0.43 \mathrm{~g}, 5.55 \mathrm{mmol})$ in diethylether $(25 \mathrm{~mL})$ was added dropwise to a solution 
of $2(0.50 \mathrm{~g}, 1.11 \mathrm{mmol})$ in diethylether $(25 \mathrm{~mL})$ at room temperature. After $16 \mathrm{~h}$ the volatiles were removed under vacuum to yield a yellow residue, which was extracted into hexane $(2 \times 20 \mathrm{~mL})$. The solvent was removed under vacuum to yield an oily mixture of $\mathbf{6}$ and $\mathbf{7}$ in a molar ratio of 1:3. NMR data for 6 and $7\left(\mathrm{C}_{6} \mathrm{D}_{6}\right):{ }^{1} \mathrm{H}: 0.82(\mathrm{~s}, 3 \mathrm{H}$, $\mathrm{Me})(6), 0.95(\mathrm{~s}, 3 \mathrm{H}, \mathrm{Me})(7), 1.24(\mathrm{~s}, 9 \mathrm{H}, t \mathrm{Bu})(7), 1.30$ $(\mathrm{s}, 9 \mathrm{H}, t \mathrm{Bu})(7), 1.37(\mathrm{~s}, 9 \mathrm{H}, t \mathrm{Bu})(6), 1.41(\mathrm{~s}, 9 \mathrm{H}, t \mathrm{Bu})$ (6), $1.47(\mathrm{~s}, 9 \mathrm{H}, t \mathrm{Bu})(6), 1.50(\mathrm{~s}, 9 \mathrm{H}, t \mathrm{Bu})(7), 1.53(\mathrm{~s}$, $9 \mathrm{H}, t \mathrm{Bu})(\mathbf{6}), 6.32\left(\mathrm{~m}, 1 \mathrm{H}, \mathrm{C}_{5} H_{4}\right)(7), 6.42\left(\mathrm{~m}, 1 \mathrm{H}, \mathrm{C}_{5} H_{4}\right)$ (6), $6.42\left(\mathrm{~m}, 1 \mathrm{H}, \mathrm{C}_{5} H_{4}\right)(7), 6.43\left(\mathrm{~m}, 1 \mathrm{H}, \mathrm{C}_{5} H_{4}\right)(6), 6.52$ $\left(\mathrm{m}, 1 \mathrm{H}, \mathrm{C}_{5} H_{4}\right)(6), 6.52\left(\mathrm{~m}, 1 \mathrm{H}, \mathrm{C}_{5} H_{4}\right)(7), 6.58(\mathrm{~m}, 1 \mathrm{H}$, $\left.\mathrm{C}_{5} \mathrm{H}_{4}\right)(6), 6.78\left(\mathrm{~m}, 1 \mathrm{H}, \mathrm{C}_{5} \mathrm{H}_{4}\right)(7),(\mathrm{NH} t \mathrm{Bu}$ not observed): ${ }^{13} \mathrm{C}$ : $5.6(\mathrm{Si} M e)(6), 7.4(\mathrm{SiMe})(7), 34.4,35.3,35.6$, 35.6, 35.8, 36.4, $37.7(\mathrm{Me}, t \mathrm{Bu})(\mathbf{6}, 7), 48.4,49.0,51.0$, 51.4, 52.3, 62.1, $62.3\left(C_{i}, t \mathrm{Bu}\right)(6,7), 104.7\left(C_{i}, C_{5} \mathrm{H}_{4}\right)(6)$, $108.2 \quad\left(C_{5} \mathrm{H}_{4}\right) \quad(6), \quad 108.4 \quad\left(C_{5} \mathrm{H}_{4}\right) \quad(7), \quad 108.5 \quad\left(C_{5} \mathrm{H}_{4}\right)$ (6), $108.8\left(C_{5} \mathrm{H}_{4}\right)(7), 113.8\left(C_{5} \mathrm{H}_{4}\right)(7), 114.5\left(C_{5} \mathrm{H}_{4}\right)(6)$, $115.5\left(C_{5} \mathrm{H}_{4}\right)(6), 116.2\left(C_{5} \mathrm{H}_{4}\right)(7),\left(C_{i}, C_{5} \mathrm{H}_{4}\right.$ in 7 not observed); ${ }^{29} \mathrm{Si}:-29(7),-41(6)$.

\section{7. $\left[\mathrm{Nb}\left\{\eta^{5}-\mathrm{C}_{5} \mathrm{H}_{4}\left[\mathrm{SiMe}(\mathrm{NHtBu})_{2}\right]\right\} \mathrm{Cl}(\mathrm{NHtBu})(\mathrm{NtBu})\right]$} (8)

A solution of $5(0.030 \mathrm{~g}, 0.080 \mathrm{mmol})$ in $\mathrm{C}_{6} \mathrm{D}_{6}$ in an NMR tube was treated with 1 equiv. of $\mathrm{LiNH} t \mathrm{Bu}$ $(0.006 \mathrm{~g}, 0.080 \mathrm{mmol})$. The reaction was immediately monitored by ${ }^{1} \mathrm{H}$ NMR spectroscopy, showing complete transformation into 8 after $5 \mathrm{~min}$. NMR data for $8\left(\mathrm{C}_{6} \mathrm{D}_{6}\right)$ : ${ }^{1} \mathrm{H}$ : $0.52(\mathrm{~s}, 3 \mathrm{H}, M e), 1.20(\mathrm{~s}, 9 \mathrm{H}, t \mathrm{Bu}), 1.22(\mathrm{~s}, 9 \mathrm{H}, t \mathrm{Bu}), 1.23$ $(\mathrm{s}, 9 \mathrm{H}, t \mathrm{Bu}), 1.36(\mathrm{~s}, 9 \mathrm{H}, t \mathrm{Bu}), 6.12\left(\mathrm{~m}, 1 \mathrm{H}, \mathrm{C}_{5} H_{4}\right), 6.15(\mathrm{~m}$,

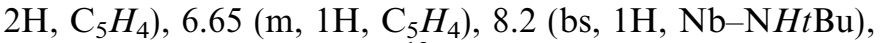
(Si-NHtBu not observed); ${ }^{13} \mathrm{C}: 4.5(\mathrm{Si} M e), 32.0(\mathrm{Me}, t \mathrm{Bu})$, $33.6(M e, t \mathrm{Bu}), 33.7(\mathrm{Me}, t \mathrm{Bu}), 33.8(M e, t \mathrm{Bu}), 49.6\left(\mathrm{C}_{i}\right.$, $\mathrm{SiNH} t B u), 49.7(\mathrm{Ci}, \mathrm{SiNH} t B u), 57.2\left(\mathrm{C}_{i}, \mathrm{NbNH} t B u\right) 68.0$ $\left(\mathrm{C}_{i}, \quad \mathrm{Nb}(\mathrm{N} t B u)\right), \quad 104.5 \quad\left(C_{5} \mathrm{H}_{4}\right), \quad 105.7 \quad\left(C_{5} \mathrm{H}_{4}\right), \quad 116.7$ $\left(C_{5} \mathrm{H}_{4}\right), 125.0\left(C_{5} \mathrm{H}_{4}\right),\left(C_{i}, C_{5} \mathrm{H}_{4}\right.$ not observed $) ;{ }^{29} \mathrm{Si}:-27.7$.

\section{Acknowledgements}

We gratefully acknowledge Ministerio de Educación y Ciencia (Project MAT2004-02614) and DGUI-Comunidad de Madrid (Project GR/MAT/0622/2004) (Spain) for financial support. L.P. acknowledges Universidad de Alcalá for fellowship.

\section{References}

[1] T. Cuenca, P. Royo, Coord. Chem. Rev. 195 (1999) 447.

[2] S. Ciruelos, T. Cuenca, R. Gómez, P. Gómez-Sal, A. Manzanero, P. Royo, Organometallics 15 (1996) 5577.
[3] R. Gómez, P. Gómez-Sal, A. Martín, A. Núñez, P.A. del Real, P. Royo, J. Organomet. Chem. 564 (1998) 93.

[4] S. Ciruelos, A. Sebastián, T. Cuenca, P. Gómez-Sal, A. Manzanero, P. Royo, J. Organomet. Chem. 604 (2000) 103.

[5] G. Jiménez, E. Rodríguez, P. Gómez-Sal, P. Royo, T. Cuenca, M. Galakhov, Organometallics 20 (2001) 2459.

[6] G. Jiménez, P. Royo, T. Cuenca, E. Herdtweck, Organometallics 21 (2002) 2189.

[7] M.I. Alcalde, M.P. Gómez-Sal, P. Royo, Organometallics 18 (1999) 546.

[8] R. Arteaga-Muller, J. Sánchez-Nieves, P. Royo, M.E.G. Mosquera, Polyhedron 24 (2005) 1274.

[9] A.L. McKnight, R.M. Waymouth, Chem. Rev. 98 (1998) 2587.

[10] H.G. Alt, A. Reb, W. Milius, A. Weis, J. Organomet. Chem. 628 (2001) 169.

[11] V.C. Gibson, S.K. Spitzmesser, Chem. Rev. 103 (2003) 283.

[12] N. Guo, L.T. Li, T.J. Marks, J. Am. Chem. Soc. 126 (2004) 6542 .

[13] J. Okuda, T. Eberle, in: Half-Sandwich Complexes as Metallocene Analogues, Metallocenes: Synthesis, Reactivity, Applications, vol. 1, Wiley-VCH, Weinheim, 1998.

[14] J. Cano, P. Royo, M. Lanfranchi, M.A. Pellinghelli, A. Tiripicchio, Angew. Chem., Int. Edit. 40 (2001) 2495.

[15] J. Cano, P. Royo, H. Jacobsen, O. Blacque, H. Berke, E. Herdtweck, Eur. J. Inorg. Chem. (2003) 2463.

[16] M. Sudupe, J. Cano, P. Royo, E. Herdtweck, Eur. J. Inorg. Chem. (2004) 3074.

[17] F. Hannig, R. Fröhlich, K. Bergander, G. Erker, J.L. Petersen, Organometallics 23 (2004) 4495.

[18] J. Cano, P. Gómez-Sal, G. Heinz, G. Martínez, P. Royo, Inorg. Chim. Acta 345 (2003) 15.

[19] G. Martínez, P. Royo, Organometallics 24 (2005) 4782.

[20] C. Ramos, P. Royo, M. Lanfranchi, M.A. Pellinghelli, A. Tiripicchio, Eur. J. Inorg. Chem. (2005) 3962.

[21] M.I. Alcalde, P. Gómez-Sal, A. Martín, P. Royo, Organometallics 17 (1998) 1144.

[22] P. Nicolás, P. Royo, M.V. Galakhov, O. Blacque, H. Jacobsen, H. Berke, Dalton Trans. (2004) 2943.

[23] P. Nicolás, P. Royo, Inorg. Chim. Acta 358 (2005) 1494.

[24] F.J. de la Mata, P. Giner, P. Royo, J. Organomet. Chem. 572 (1999) 155.

[25] M.I. Alcalde, M.P. Gómez-Sal, P. Royo, Organometallics 20 (2001) 4623.

[26] S. Ciruelos, T. Cuenca, P. Gómez-Sal, A. Manzanero, P. Royo, Organometallics 14 (1995) 177.

[27] O. Buitrago, G. Jiménez, T. Cuenca, J. Organomet. Chem. 683 (2003) 70.

[28] B. Royo, P. Royo, L.M. Cadenas, J. Organomet. Chem. 551 (1998) 293.

[29] A.B. Vázquez, P. Royo, E. Herdtweck, J. Organomet. Chem. 683 (2003) 155.

[30] A.B. Vázquez, P. Royo, J. Organomet. Chem. 671 (2003) 172.

[31] A.B. Vázquez, Ph.D. (2003) Universidad de Alcalá.

[32] D. Santamaría, J. Cano, P. Royo, M.E.G. Mosquera, T. Cuenca, L.M. Frutos, O. Castaño, Angew. Chem., Int. Edit. 44 (2005) 5828.

[33] A.M. Andreu, F.A. Jalón, A. Otero, P. Royo, A.M.M. Lanfredi, A. Tiripicchio, J. Chem. Soc., Dalton Trans. (1987) 953.

[34] M.C. Maestre, V. Tabernero, M.E.G. Mosquera, G. Jiménez, T. Cuenca, Organometallics 24 (2005) 5853. 